\title{
Policy Fiasco: The Sabotage of Cabotage Policy Malaysia
}

\author{
Firdausi Suffian, Mohammed Rahezzal Shah Abdul Karim, Abdul Kadir Rosline, and Kamal Solhaimi \\ Fadzil
}

\begin{abstract}
This paper argues that Cabotage policy as a non-tariff barrier has harmed the domestic economy and is inconsistent with the premise of trade liberalisation agenda. The effect of Cabotage policy limits market access and has formed monopoly in the shipping industry. The policy might increase efficiency in term of technology and consolidating resources in one participant of the industry but does not improve the overall welfare the industry. This paper proposes a mid-way-out approach by taking incremental steps towards change and requires a committee system to review and streamline the Cabotage policy. We named the committee as logistic committee that envisioned working on towards liberalizing the transportation and logistics industry. It is proposed that the committee decision as binding and as primary source of policy making input.
\end{abstract}

Index Terms-Cabotage policy, committee systems, incrementalism, protectionism.

\section{INTRODUCTION}

Malaysia is a trade dependent nation in which the service industry plays an important role towards sustaining the nation's economic activities. A key factor for investors looking to embark on a business venture in any country is the effectiveness of the service sector, particularly, in the context of transportations and logistics. With the establishment of the Malaysia International Shipping Corporation (MISC) by the Malaysian government in 1968 marked the entry of Malaysian shipping industry into international shipping. Indicating a strong interest to compete in the international shipping industry, in 1982, MISC pioneered the introduction of containerised shipping in Malaysian domestic trade. Over the years, the government has tried to elevate Malaysian's service industry to a level of international competitiveness. The government has invested considerable amount of money to ensure the service sector achieves this goal (Mun 2007). Malaysia government has invested heavily in strengthening the local shipping industry and improves the physical infrastructures.

Currently, MISC remains the owner and operator of the largest fleet of Malaysian registered containerships with 27 vessels, placing MISC in the $17^{\text {th }}$ ranking for the world's top 20 containership owner-operator league based on Clarkson Containership Register [1]. The government efforts to strengthen its shipping industry has also helped to emerge

Manuscript received May 12, 2013; revised July 10, 2013.

F. Suffian, M. R. S. Abdul Karim, and A. K. Rosline are with the Universiti Teknologi MARA Cawangan Sabah, Locked Beg 71, 88997 UiTM Sabah Kota Kinabalu (e-mail: firdausi@sabah.uitm.edu.my, rahezzal@sabah.uitm.edu.my, akrosline@sabah.uitm.edu.my).

K. S. Fadzil is with University Malaya 50603 Kuala Lumpur (e-mail: Kamalsolhaimi@hotmail.com). few number of local shipping companies, mainly Bumiputra ownership, that involve in international trade such as Halim Mazmin Berhad, Nepline, Global Carriers, PDZ, and Malaysian Merchant Marine Berhad [2]. Nevertheless, Malaysian merchant fleet remains small by global standards carrying less than 20 per cent of Malaysian cargo. The development of Malaysian shipping industry is closely linked to national policy. Over the years the government has been working at promoting the growth of the national merchant fleet to have a larger share as a carriage for international cargo on national flagged ships. The government still deems the maritime industry in Malaysia as being at its infancy stage thus it has adopted more protective measure to ensure the industry will grow and achieve the necessary economies of scale [3]. Hence, the government's primarily aim is to reduce severe outflows of freight payment to non-national shipping lines. To achieve this goal, the government introduced the Cabotage policy with the aim of protecting the national shipping company under the rubric of setting national shipping sight on moving towards self-sufficiency so that they are able to grow over the years.

This paper argues that Cabotage policy as non-tariff barriers limits market access and does more harm than good to the domestic economy. It is thus important that this issue be addressed for both the betterment of the national economy, and more so, for the growth of the east Malaysian economic growth. This paper is a preliminary attempt at exploring this subject and as point of departure for scholarly debate. Firstly, the paper will explain the details of the Cabotage policy that was introduced in 1980. Secondly the paper will examine the downside of the policy on domestic economic growth in East Malaysia, particularly the state of Sabah. Lastly, this paper will explore alternative solutions for the problem.

\section{Overview of CABotage Policy}

The term 'Cabotage' refers to the "reservation to a country of traffic (coastal water) operation within its territory [4]. It is an exclusive right for companies to operate within the domestic borders of another country. Cabotage regulations that limit other companies to trade within the country territories might constitute to trade restriction policy. Cabotage policy in Malaysia was introduced in 1980 to protect and help develop Malaysia's domestic capacity in trade and logistics. The policy requires that all ports comply regardless of whether or not it is under the purview of the state government or Maritime department. The policy stated that domestic trades between any two ports in the country only to be served by Malaysian-owned shipping companies $[5]$.

The introduction of the policy led to the amendment of 
Merchant Shipping Act 1952 section 65A which defines 'domestic shipping' for the shipment of goods or carriage of passengers (i) from any port or place in Malaysia to another port or place in Malaysia or (ii) from any port or place in Malaysia to any place in the exclusive economic zone and vice versa. According to the Act, to own a Malaysian ship the person(s) must be a Malaysian citizen(s) or corporation, which satisfy the requirement such as (i) Corporation is incorporated in Malaysia (ii) Principle office of the corporation is in Malaysia (iii) Management of the corporation is carried out mainly in Malaysia (iv) Majority, or if the percentage is determined by the Minister, then the percentage so determined, of the shareholding, including the voting share, of the corporation is held by Malaysian citizen free from any trust or obligation in favor of non-Malaysian (v) Majority, or if the percentage is determined by the Minister, then the percentage so determined, of the directors of the corporation are Malaysian citizen

The government also appointed the Domestic Shipping Licensing Board (DSLB) to regulate and control the licensing of ship this is in line with the MSA 1952 Part II 'Qualification of International Ship Registry'. Furthermore there are other criteria for companies intending to apply for the 'unconditional license'. For this licence, the company is required to fulfil two criteria; firstly, $30 \%$ Bumiputra participation in terms of equity, directorship and office staff and, secondly, it employs $75 \%$ Malaysian citizen as ratings on the vessels. The aim of the policy is to encourage local participation particularly the Bumiputra in the shipping industry. The policy explicitly protects the domestic industry by limiting foreign market access in the local maritime industry. Implicitly, the nature of the policy has given the government a monopoly over the power to decide whom, how and when applicants receive the shipping license and access to domestic market. The policy may hold good however discriminating foreign competition may lead to unfair practices that may do more harm the domestic market.

\section{THE DOWNSIDE}

Cabotage policy is a barrier to trade which limits foreign competition that is intended to pursue national interest in local infant shipping industry to grow [6]. The Cabotage policy may aim to facilitate the local shipping industry e.g. Malaysia International Shipping Corporation (MISC) and member of Malaysia Shipowner Association (MASA) to grow and become self-sufficient, but after 32 years this policy seems to be anachronistic because it does not really serve the purpose of making the Malaysia Shipping Industry more competitive rather it has harmed domestic growth and distorted competition in the local maritime industry. The policy serves as trade barriers cause industry unable to mobilise their capital according to their comparative advantage [7] and creates inefficiency in resource allocation. Thus industry unlikely to achieve its economies of scales and does not increase welfare gain.

For Sabah's economic growth, the Cabotage policy remains a bottleneck due to its imposition and limited market access. According to the President of Federation of Manufacturing Sabah (FSM) Datuk Wong Khen Tau, who argues that the Cabotage policy failed to benefit domestic shipping lines and continues to contribute to the high cost of goods in Sabah. However, Chairman of Malaysian Shipowners Association (MASA), Ir. Nordin Mat Yusoff, propounds that high cost of goods could not be associated with freight charges solely. There are other factors that may contribute to the higher retail price in Sabah, among others, lack of manufacturing sectors. Both positions, for and against the Cabotage policy have made strong points for their cause. The former point outs high transaction cost causes price discrimination between the west and east Malaysia. The latter argues that shipping cost could not be deemed as the sole variables that lead to price distortion. To some extent Nordin may have a point that Cabotage policy is not the only factors that determine price discrimination. It is quite difficult to contend that the policy has clear causal relationship to higher cost of goods in Sabah. However, with the presence of protectionist policy, clearly it would limit participation of firm in the economic activities. This leads to unfair competition and distort price formation in the market, thus in such interventionist context make price becomes less competitive [8]

Cabotage policy in Malaysia limits participation of firm in the market, which then allow Malaysia shipping company to be 'selective' in positioning indigenous carriers. For instance Malaysia International Shipping Corporation (MISC) that Petronas holds its shares $65 \%$. So the focus is on tanker fleet to cater largely crude oil to be shipped abroad. With the presence of the Cabotage policy that limit carriers participation in the shipping industry, MISC has no option but to operate in space-sharing alliances placing MISC in a weak position in bringing about change or to support national objectives [9]. This scenario shows that limited participation causes inefficiency and monopoly in the industry. Theoretically protectionist policy should allow competition from within. Like Cabotage policy, such protectionism presumably promotes learning for protected private firms to grow, since there is less competition and state could focus on managing firm's resources [10] gradually, the policy aims to increase more local private shipping company to enter the market. Nevertheless, the policy seems to give Malaysia shipping industry more incentive to use most resources and technology invested in vessel and tanker fleet in favour of Petronas. Cabotage policy also creates 'natural monopoly' that gives MISC advantage in shipping most of the goods abroad. Similarly the other Malaysia shipping company under the Malaysia Shipowner Association (MASA) benefits from the shipping industry monopoly. Natural monopoly that forms from protectionist tools should allow firms to utilise resources effectively and improve domestic market. But this advantage given to local shipping industry i.e. MISC and MASA do little to develop more vessels carrying goods from west to east Malaysia.

\section{LOOKING FOR ALTERNATIVE}

The 32 years old anachronistic policy needs to be reviewed for effectual change. To do away with the Cabotage policy may not be easy at this point in time, maintaining the policy, as status quo is counterproductive. Nevertheless, gradual 
change is plausible. At the outset, the Equal Opportunity Commission (EOC) established under the Strategic Reform Initiatives (SRIs) in the New Economic Model 2010 [11] should review the policy. The aim of this commission is to ensure fairness and to address any undue discrimination brought about by dominant groups. This commission was intended to reduce the market power of the organised group who has monopoly control in certain sectors (NEM 2010). Due to from right wing Malay nationalist groups such as PERKASA, the EOC has been decommissioned [12].

A feasible starting point, government could adopt the Mid Way Out Approach [13]. This approach aims for a structural change in the system by incorporating a 'committee system' to review policy changes. Government can initiate a 'logistic committee' that discusses how the policy can be re-formulated to reduce its negative implications. The composition of the committee members is important if there are to make incremental but significant changes. Committee members should a represent a mix of both administrators and implementers and not lean to heavily on either end. An unbalanced mix may cause for over emphasize on one agenda rather than a more nuanced approach to addressing the problem. Policy decision making need to be done by actors whose power formulates policies is derived by virtue elites [14]. The committee members should consist of those who understand the interest of the public namely, private sectors, civil society, professional groups and representatives from Sabah and Sarawak. The Chairman of the Logistic Committee should be the Minister of Transportation. Sabah and Sarawak representatives should also be given a central position as they are most affected by Cabotage policy.

In line with the PM Najib's call for greater transparency and accountability in governance, the committee system can be a demonstration on how the Ministry of Transportation can operate in a more transparent and accountable way. This is possible, because with the presence of a Logistic Committee $(L C)$, it will provide for an avenue for both state representatives and other stakeholders to discuss with regards to transportation and logistics policy (this includes trade facilitation). In addition, to indicate that the members of the LC are not tokens, it is suggested that the members' decision should be binding and deemed as a primary source of policy input for the Ministry of Transportation. With such an initiative, the government may be able to address the problem arising from natural monopoly that exists in the shipping industry. With more transparency and accountability, the shipping industry could operate in pare to efficiency ${ }^{1}$. This means that the shipping industry can be improved by reducing the monopoly, increasing more domestic player in the shipping industry. Hence it makes the market more competitive and improves welfare gain for all participants. This committee system could also enhance 'credible commitment' of members through consistent interaction among representatives to come out with more feasible

\footnotetext{
${ }^{1}$ If changes in economic policy reduce a monopoly and that market subsequently becomes competitive and improve welfare gain. The monopolist will be made a 'little' worse off. However, the loss to the monopolist will be more than offset by the gain in efficiency. This means the monopolist can be compensated for its loss while still leaving a net gain for others in the economy [15].
}

Cabotage policy and prepare for further liberalisation in the future.

\section{CONCLUSION}

Cabotage policy as non-tariff barriers, it may have helped to shield foreign competition but it has also harmed domestic economic growth particularly in East Malaysia. The implications of the cabotage policy causes limited market access and natural monopoly in the shipping industry. Protectionism is supposed to allow a government to mobilise resources for infant industry to grow. Resources invested in infant industry should improve domestic firms' learning curve, making them more competitive. However the policy has adversely impacted on domestic shipping industry, slowing down the East Malaysia export-oriented growth. This paper suggests that the next best option to solve the problem related to the present practice of the Cabotage policy is through the formation of a logistic Committee (LC) as mid-way out solution. The composition of the committee members is of central importance to the effectiveness of making incremental change. The representation of committee should consist of those who understand the interest of the public namely, private sectors, civil society, professional groups and representative from Sabah and Sarawak. The Chairman of the LC will be the Minister of Transportation. Sabah and Sarawak representatives are central in this committee because they are most affected by the Cabotage policy. It is proposed that the decision of LC should be binding and become central input to policy decision-making. This also reflects the virtue of transparency and accountability as espoused by the federal government. It is also argued that a credible commitment towards a solution to the cabotage policy such as through the LC will be a catalyst for representatives to introduce further liberalization in the shipping

\section{REFERENCES}

[1] UNESCAP. (2002). Free Trade Zone and Port Hinterland Development. [Online]. Available: http:// www.unescap.org/ttdw/publications/tfs.../ftz fulltext.pd

[2] Malaysianship. [Online]. Available: www. Malaysianshipowners.com

[3] B. Balassa, Comparative Advantage, Trade Policy and Economic Development, New York/London: Harvester Wheatsheaf, 1989.

[4] European Commission 2010, "Time to decide European Transport Policy."

[5] National Maritime Malaysia 2010. [Online]. Available: http:// www.postworld.com

[6] D. Rodrik, "Industrial policy for the twenty-first century, Centre for Economic Policy Research," Discussion Paper Series, no. 4767, 2004.

[7] P. Krugman, "Growing world trade: Causes and consequences," Brookings Paper and Economic Activity, Standford University, 2001.

[8] T. Besley and L. Cord, "Delivering on the promise of pro-poor growth: Insight and lessons from country experiences," New York: Palgrave Macmillan and the World Bank, 20007.

[9] PDP Australia Pty Ltd and Meyrick \& Associates, "Promoting efficient and competitive INTRA-ASEAN shipping services," REPSF Project 04/001, 2005.

[10] J. E. Stiglitz and A. Charlton, Fair trade for all: How trade can promote development, Oxford University Press, 2010.

[11] New Economic Model. (2010). [Online]. Available: http:// www.pmo.gov.my.

[12] T. Pua, The Need to Reinstate NEM's Equal Opportunity Commission, Malaysian Digest, 2010.

[13] F. Suffian, M. R. S. Karim, and A. K. Rosline, "Local government and good governance: selection committee for local councillors and the 
deconsolidation of patron-client network at local governance in Malaysia," Man and Society, vol. 4, pp. 1-22, 2011.

[14] P. Deleon, "The missing link revisited: contemporary implementation research," Policy Studies Review, vol. 16, no. 3-4, pp. 311-338, 1999.

[15] N. Barr, Economics of the welfare state, New York: Oxford University Press (USA), 2004.

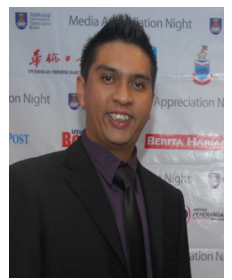

Firdausi Suffian is a lecturer of public policy specializes in policy analysis at Faculty of Administrative Science and Policy Studies Universiti Teknologi MARA (Malaysia) Sabah. He obtained his bachelor degree of administrative science (first class honours) from Universiti Teknologi MARA (Malaysia) Sabah and master degree of public policy specialising in policy analysis from Australia National University, Crawford Schools of Economics and Government. His research interests are in public policy, governance, democracy, political economy and public opinion.
He was also appointed to be the consultant for United Nation Child Fund to oversee the documented and undocumented child in Sabah. His research on situational analysis with regard to children in Sabah has been an important guideline for the state government to reformulate welfare policy. He is also a regular columnist in Borneo Post which is one of the widely read newspaper in Borneo. He also holds an administration position in Universiti Teknologi MARA (Malaysia) Sabah as Coordinator of Corporate Relations Unit.

Firdausi was a former Member of Youth Parliament Malaysia who has been actively advocating young generation rights and contributes new ideas for government policy. He is also an advisor to the university debating society and member of UiTM Sabah Alumni Association that actively assisting those who are underprivileged to get access to higher learning education. He has presented his academic work around Asian countries 